\title{
Model Penentuan Suhu Kritis Pada Sapi Perah Berdasarkan Kemampuan Produksi Dan Manajemen Pakan
}

(The Model of Critical Temperature of Dairy Cattle on product ability and feed management )

\section{Suherman, B.P. Purwanto, W. Manalu', I.G. Permana}

1) Bagian Disertasi di Sekolah Pascasarjana IPB

2) Mahasiswa Program Doktor pada Mayor ITP, SPs. IPB

3) Dept. ITP FAPET-IPB. Ketua Komisi Pembimbing

4) Bagian Fisiologi FKH-IPB. Anggota Komisi Pembimbing

5) Dept. Ilmu Nutrisi Ternak FAPET-IPB. Anggota Komisi Pembimbing

\begin{abstract}
A research was conducted in Jakarta and Bogor and during January 2011 until February 2011. The objective of research were to measure effects of critical temperature (air temperature and humidity) on indicate physiological responses for critical temperature of Fries Holland Heifer.They were fed twice daily with grass and concentrate. Six dairy heifers were used in the research. The Indicate physiological responses were skin temperature, rectal temperature, and body temperature for 14 days. The results show that critical temperature on physiogical responses were significantly better on cattle for ANN which for critical temperature in Jakarta and Bogor that with the same and significantly better too on cattle which rectal temperature and skin temperature in Jakarta and Bogor.
\end{abstract}

Key words: critical temperature, heifer, indicate physiological responses, ANN

\begin{abstract}
ABSTRAK
Penelitian ini dilakukan di Jakarta dan Bogor dari bulan Januari hingga Pebruari 2012.Penelitian ini bertujuan untuk menentukan suhu kritis (suhu dan kelembaban udara) pada sapi dara peranakan Fries Holland berdasarkan indikator respon fisiologis.Pakan diberikan dua kali setiap hari dengan rumput dan konsentrat.Enam ekor sapi dara yang digunakan dalam penelitiannya.Parameter respon fisiologis yang diamati meliputi suhu kulit, suhu rektal, dan suhu tubuh selama 14 hari. Hasil penelitian menunjukkan bahwa terdapat perbedaan suhu kritis pada sapi dara yang dihitung dengan program Artificial Neural Network (ANN) di dareah Jakarta dan Bogor. Berdasarkan indikator respon fisiologis untuk menentukan suhu kritis dengan program ANN yang paling sensitif melalui suhu rektal dan suhu kulit baik di Jakarta maupun Bogor
\end{abstract}

Kata kunci: suhu kritis, sapi dara, indikator respon fisiologis 


\section{PENDAHULUAN}

Lingkungan merupakan salah satu faktor yang mempengaruhi produktivitas ternak sapi perah. Keunggulan genetik seekor ternak sapi perah tidak akan ditampilkan optimal apabila faktor lingkungannya tidak sesuai. Salah satu faktor lingkungan yang menjadi kendala tidak terekspresinya sifat genetik ternak adalah lingkungan mikro(Esmay 1978). Faktor-faktor lingkungan mikro yang menjadi kendala terutama adalah suhu udara, kelembaban udara, radiasi matahari, dan kecepatan angin (Gebremedhin 1985; Santosoet al. 2003), sehingga perlu upaya pengendalian lingkungan mikro agar produktivitas ternak sapi perah dapat ditingkatkan.

Sapi perah dapat hidup dengan nyaman dan berproduksi secara optimum bila faktor-faktor internal dan eksternal berada dalam batasanbatasan normal yang sesuai dengan kebutuhan hidupnya. Suhu lingkungan merupakan salah satu factor eksternal yang dapat mempengaruhi kenyamanan dan produktivitas sapi perah. Lingkungan suhu kritis dan cekaman panas pada peternakan sapi perah menjadi salah satu masalah utama karena dapat menyebabkan kerugian ekonomi akibat penurunan produktivitas (StPierre et et al. 2003). Pada saat akhir abad 19 dan abad 20 ditandai dengan meningkatnya rataan temperatur global dari 0,8 menjadi $1,7^{\circ} \mathrm{C}$ Akibatnya terjadi peningkatan rataan temperatur global selama 5 tahun terakhir. Oleh karena itu, diduga terjadi pergeseran kisaran suhu termonetral dan suhu kritis pada sapi perah .

Sebagian besar sapi perah yang ada di Indonesia adalah sapi bangsa Fries Holland (FH), yang didatangkan dari negara-negara Eropa dan memiliki iklim sedang (temperate) dengan kisaran suhu termonetral rendah berkisar $13-18^{\circ} \mathrm{C}$ (McDowell 1972), 5-25ㄷ (McNeilly 2001). Kondisi asal iklim tersebut, sapi perah $\mathrm{FH}$ sangat peka terhadap perubahan iklim mikro terutama suhu dan kelembaban udara tinggi menyebabkan cekaman panas dan berakibat menurunnya produktivitas.Strategi mengurangi cekaman panas dapat dilakukan dengan perbaikan pakan, perbaikan konstruksi kandang, pemberian naungan pohon dan air minum ad libitum (Velasco et al. 2002).

Model penentuan suhu kritis berdasarkan pada respon fisiologis sapi perah cukup intensif dilakukan di daerah subtropis.Namun demikian, penentuan suhu kritis berdasarkan pada respon fisiologis sapi perah yang dipelihara di dataran rendah dan dataran sedang dari daerah tropis pada usaha peternakan rakyat, khususnya Indonesia, masihbelum dilakukan secara menyeluruh serta berkesinambungan.Selain itu hasil penentuan suhu kritis dari daerah 
subtropis belum tentu cocok diterapkan di daerah tropis, akibat lingkungan mikro berbeda sehingga diduga memberikan hasil berbeda.

Di daearah tropis, daya tahan ternak terhadap panas merupakan salah satu faktor yang sangat penting agar ternak berproduksi optimal sesuai kemampuan genetis yang dimiliki. Ternak yang tidak tahan terhadap panas, produktivitasnya akan turun akibat dari menurunnya konsumsi pakan. Sementara itu ternak yang tahan terhadap panas dapat mempertahankan suhu tubuhnya dalam kisaran yang normal tanpa mengalami perubahan status fisiologis dan produktivitas (Tyler danEnseminger 2006).

Proses mempertahankan suhu tubuh tersebut dikenal dengan proses termoregulasi atau pengaturan panas. Proses ini terjadi bila sapi perah mulai merasa tidak nyaman. Proses termoregulasi pada prinsipnya adalah keseimbangan panas antara produksi panas dan pelepasan panas (Yousef 1985). Ternak akan memproduksi panas dalam tubuhnya sebagai upaya menghasilkan energi yang diperlukan untuk kehidupannya (beraktifitas dan penyesuaian terhadap lingkungan). Panas yang diproduksi tergantung dari aktifitas ternak dan intake pakan, feed intake dinyatakan dalam TDN yang menunjukkan total bahan pakan dapat dicerna oleh ternak (Rahardja 2007). Perolehan panas dari energi pakan akan menambah beban panas bagi ternak bila suhu udara lebih tinggi dari suhu nyaman dan sebaliknya kehilangan panas bila suhu udara lebih rendah dari suhu nyaman.

Penelitian mengenai sifat daya tahan panas telah banyak dilakukan pada sapi perah berdasarkan pada sumber panas dari luar tubuh, sedangkan sumber panas dari dalam tubuh seperti waktu pemberian pakan belum banyak dilakukan. Panas ini memberikan makna esensial untuk mempertahankan suhu tubuh dan laju metabolisme yang tinggi pada sapi perah, sehingga dapat menghasilkan produktivitas yang normal. Akan tetapi sebaliknya di lingkungan dengan suhu yang tinggi, EKP merupakan tambahan beban panas dan menurunkan produksi (West 2003; Pennintong dan van Devender 2004).

Pada tempat-tempat tertentu bagi pengembangan sapi perah $\mathrm{FH}$ di daerah tropik, suhu lingkungan siang hari mencapai $27^{\circ} \mathrm{C}$ selama lebih dari 6 jam. Hal tersebut dapat menyebabkan sapi mengalami suhu kritis dan akhirnya mengalamicekaman panas berkelanjutan sehingga produksi maksimal tidak akan tercapai. Dalam keadaan suhu kritis dan cekaman panas diperlukan energi tambahan untuk meningkatkan pembuangan panas melalui penguapan kulit dan pernapasan, akibatnya produksi menurun. Oleh karena itu, perlu adanya suatu penelitian tentang penentuan batas suhu kritis berdasarkan kemampuan produksi dan manajemen pakan di daerah tropik pada dataran sedang dan rendah untuk meningkatkan produksi 
yang dihasilkan. Penentuan lingkungan suhu kritis berdasarkan kemampuan produksi dan manajemen pakan pada sapi perah diharapkan sebagai dasar untuk menentukan respon fisiologis dan kehilangan panas melalui penguapan dari permukaan kulit, sehingga akan memperbaiki keseimbangan panas, selanjutnya akan meningkatkan konsumsi pakan dan produksi.

Suhu dan kelembaban udara berpengaruh langsung terhadap perubahan fisiologis sapi perah, sehingga akhirnya akan berdampak pada produksi. Pada keadaan suhu dan kelembaban tinggi akan terjadi penentuan antara imbangan proses perolehan panas (produksi panas metabolisme dan perolehan dari lingkungan) dengan pembuangan panas dalam rangka memelihara tingkat suhu tubuh normal. Semakin tinggi suhu lingkungan $\mathrm{di}$ atas Thermoneural zone akan menyebabkan perolehan panas lebih banyak daripada pembebasan panas, akibatnya peningkatan suhu tubuh. Bila suhu tubuh meningkat, akan terjadi usaha ternak untuk mengeluarkan panas dengan cara radiasi, konduksi, konveksi, dan evaporasi, yang mengakibatkan terjadinya peningkatan konsumsi air minum dan menurunkan konsumsi pakan, serta energi yang digunakan untuk mengatur suhu tubuh meningkat. Peningkatan suhu tubuh tersebut akan meningkatkan laju metabolisme dalam sel. Namun adanya pengaturan homeostasi melalui hormonal, akan menurunkan laju produksi panas.

Hasil penelitian ini diharapkan dapat memberikan informasi mengenai model penentuan batas suhu kritis sapi perah dara berdasarkan respon fisiologis di dua daerah dengan lingkungan yang berbeda. Informasi mengenai suhu kritis berdasarkan respon fisiologis akan digunakan sebagai dasar pengembangan sapi perah.

\section{MATERI DAN METODE}

Penelitian dilakukan di Laboratorium lapangan, unit produksi ternak perah Departemen Ilmu Produksi dan Teknologi Peternakan Fakultas Peternakan IPB Bogor dan Kebon Pedes Bogor sebagai daerah topografi sedang (400-600 dpl), dan peternakan sapi perah rakyat di Pondok Rangon Jakarta Timur sebagai topografi rendah (200-400 dpl). Lama penelitian dilaksanakan masingmasing daerah selama satu bulan serta dimulai dari bulan Januari 2011 hingga Februari 2011.

Kegiatan penelitian kajian untuk menganalisis penentuan batas suhu kritis sapi perah dara dalam kandang berdasarkan respon fisiologis pada masing-masing waktu dan suhu lingkungan serta berbeda daerah. Enam ekor sapi dara PFH menempati tiap petak kandang. Sapi-sapi dipelihara selama 14 hari, dengan kurun waktu tersebut setiap hari diberikan pakan pada pagi hari pukul 
06.00 - 07.00 dan sore hari pukul 15.00 - 16.00 dengan $60 \%$ rumput dan $40 \%$ konsentrat. Selama pengamatan sapi tidak dimandikan.

Rancangan penelitian secara purposive untuk menganalisis penentuan batas suhu kritis sapi perah dara dalam kandang berdasarkan respon fisiologis pada masing-masing waktu dan suhu lingkungan dengan berbeda daerah. Selanjutnya dilakukan pengamatan respon fisiologis pada masing-masing waktu dan suhu lingkungannya, dari pukul 5.00 hingga pukul 20.00 dengan selang waktu pengamatan satu jam.

Parameter yang diamati terdiri atas faktor iklim dan respon fisiologis sapi perah. Faktor iklim yang diukur meliputi suhu udara bola basah dan bola kering (DBT-WBT), kelembaban udara (RH), kecepatan angin, dan menghitung Temperature Humidity Indeks (THI). Pengamatan suhu udara dan kelembaban dalam kandang dilakukan setiap hari dari pukul 05.00 hingga pukul 20.00 dengan selang waktu satu jam selama 14 hari. Respon fisiologis sapi yang diukur adalah suhu permukaan kulit (Ts), suhu rektal (Tr), dan menghitung suhu tubuh (Tb). Pencatatan suhu permukaan kulit (Ts), suhu rektat (Tr), dan suhu tubuh $(\mathrm{Tb})$ dilakukan selama 14 hari dari pukul 05.00 hingga pukul 20.00 dengan selang waktu satu jam.

\section{Metode Pengukuran Parameter}

1. Suhu dan kelembaban udara diukur dengan termometer bola basah dan bola kering. Pengukuran dilakukan di dalam kandang.

2. Indeks suhu kelembaban (THI) dihitung menggunakan rumus Hahn (1985) yaitu : THI = DBT + 0,36 $\mathrm{WBT}+41.2, \mathrm{DBT}=$ suhu bola kering $\left({ }^{\circ} \mathrm{C}\right)$ dan $\mathrm{WBT}=$ suhu bola basah $\left({ }^{\circ} \mathrm{C}\right)$.

3. Kecepatan angin diukur menggunakan anemometer digital yang diletakkan di dalam kandang. Anemometer di buka selama 15 menit kemudian di baca kecepatan rata-rata tiap detiknya.

4. Suhu permukaan kulit (Ts), diukur pada empat titik lokasi pengukuran yaitu punggung(A), dada (B), tungkai atas (C), dan tungkai bawah (D). Rataan suhu permukaaan kulit dihitung berdasarkan rumus McLean et al. (1983); Ts $=0.25(\mathrm{~A}+\mathrm{B})+0.32 \mathrm{C}+$ $0.18 \mathrm{D}$.

5. Suhu rektal (Tr), diukur dengan memasukkan termometer klinis ke dalam rektal sedalam $\pm 10 \mathrm{~cm}$ selama tiga menit.

6. Suhu tubuh (Tb), dihitung dari suhu permukaan kulit (Ts) dan menjumlahkan dengan suhu rektal (Tr) menurut McLean et al. (1983). Suhu tubuh $(\mathrm{Tb})$ dihitung dengan rumus : $\mathrm{Tb}=0.86 \mathrm{Tr}+0.14 \mathrm{Ts}$

Analisis data berupa penentuan batas suhu kritis pada sapi dara $\mathrm{PFH}$ 


\section{HASIL DAN PEMBAHASAN}

\section{Kondisi Lingkungan Iklim Mikro}

Perubahan-perubahan pada panas lingkungan sangat tergantung dari kondisi udara lingkungan yang meliputi suhu udara, kelembaban udara, radiasi matahari, kecepatan angin, kepadatan kandang, dan karakter pelepasan panas metabolis tubuh ternak (Berman 2008). Hasil pengamatan selama penelitian yang berlangsung dari pukul 05.00 hinggga pukul 20.00, kondisi lingkungan iklim mikro di daerah Bogor dan Jakarta, berupa kisaran suhu udara berkisar antara $22-33^{\circ} \mathrm{C}$ dan $23,50-33,50^{\circ} \mathrm{C}$, kelembaban udara antara 53-91\% dan $56-88 \%$, kecepatan angin antara 0-0,9 $\mathrm{m} / \mathrm{s}$ dan $0-0,6 \mathrm{~m} / \mathrm{s}$, dan nilai THI berkisar antara 70,94-83,92 dan 72,8084,42 (Gambar 1). Nilai suhu dan kelembaban udara tersebut menunjukkan kondisi lingkungan ternak berpotensi memberikan suhu kritis dan cekaman fisiologis pada sapi dara peranakan FH. Kisaran zona termonetral ternak berada pada suhu udara antara $13-18^{\circ} \mathrm{C}$ (McDowell 1972), $5-25^{\circ} \mathrm{C}$ (Jones dan Stallings 1999), suhu udara antara $13-25^{\circ} \mathrm{C}$ dan kelembaban udara antara 50-60\% (McNeilly 2001). Suhu dan kelembaban lingkungan yang ideal bagi penampilan produksi sapi perah peranakan $\mathrm{FH}$ akan dicapai pada suhu udara $18,3^{\circ} \mathrm{C}$ dan kelembaban udara 55\% (Sutardi 1981), serta penampilan produksi masih cukup baik bila suhu lingkungan meningkat sampai $21,1^{\circ} \mathrm{C}$ serta suhu kritis sebesar $27^{\circ} \mathrm{C}$ (Sudono et al. 2003).

Kondisi pada pagi hari (pukul 05.00-09.00) relatif sama dengan sore hari (pukul 16.00-20.00), baik di daerah Bogor maupun Jakarta. Suhu udara pagi hari relatif sesuai untuk sapi dara FH, akan tetapi kelembaban udara kurang sesuai, karena berada di atas kisaran normal. Pada sore hari, terjadi cekaman udara diakibatkan kelembaban udara. Rataan nilai THI sore hari sebesar 75 di daerah Bogor dan sebesar 76 di daerah Jakarta menunjukkan terjadinya cekaman ringan. Suhu udara pada sore hari menurun, akan tetapi kelembaban udara meningkat. Sementara itu, kecepatan angin pada sore hari relatif belum cukup untuk mengurangi beban panas tubuh ternak. Kelembaban udara tersebut dapat menjadi faktor penghambat proses konveksi dan evaporasi ternak. Bohmanova (2007) menyatakan bahwa kelembaban udara merupakan faktor penghambat proses stress panas pada iklim lembab dan suhu udara kering adalah faktor pembatas stress panas pada iklim kering.

Pada Gambar 1, pukul 05.00 hingga 09.00 kondisi suhu udara, kelembaban udara dan THI berpotensi menyebabkan cekaman ringan. Cekaman lebih disebabkan tingginya kelembaban udara pada pukul tersebut. Berdasarkan nilai suhu udara dan THI tersebut, bagi sapi perah mengindikasikan mengalami suhu kritis. Apabila suhu udara meningkat diatas suhu termonetral sapi akan 
mulai menderita suhu kritis atau dimulainya menderita cekaman, sehingga mekanisme termoregulasi mulai bekerja terutama dengan cara meningkatkan pernafasan, denyut jantung dan penguapan air melalui kulit. Untuk mengetahui status suhu kritis pada ternak dapat dilakukan dengan mengetahui suhu tubuh yang diestimasikan dari hasil pengukuran suhu rektal dan suhu kulit, sedangkan untuk mengetahui tingkat pembuangan panas tubuh (heat loss) dapat dilakukan dengan mengetahui suhu kulit, frekuensi pernafasan dan denyut jantung (Purwanto 1993). Daerah termonetral bagi ternak merupakan kisaran suhu udara dan THI yang paling sesuai untuk kehidupannya, dimana terjadi metabolisme basal dan hanya terjadi mekanisme pengaturan panas secara sensible dengan menggunakan energi yang paling sedikit. Kisaran suhu udara tersebut tidak menyebabkan peningkatan atau penurunan fungsi tubuh (McDowell 1972; Yousef 1985), terjadinya metabolisme basal pada kisaran suhu termonetral tersebut berarti pula produksi panas tubuh sangat rendah. Kecepatan angin pada pukul 05.00 hingga pukul 07.00 (Gambar 1) sangat rendah dan bernilai $0 \mathrm{~m} / \mathrm{s}$ sehingga angin belum cukup berfungsi untuk membantu pelepasan panas dan mereduksi beban panas tubuh ternak (Yani dan Purwanto 2006).

Pada siang hari (pukul 10.0015.00), suhu udara dan THI meningkat hingga pukul 13.00 di daerah Bogor dan Jakarta (pukul 12.00), sebaliknya kelembaban udara menurun, akan tetapi kelembaban tersebut tetap pada nilai yang berpotensi memberikan suhu kritis ternak atau cekaman panas, baik di daerah Bogor maupun Jakarta. Nilai rataan THI pada pukul 12.00 dan pukul 13.00 adalah yang tertinggi di daerah Bogor yaitu sebesar 82, tetapi di daerah Jakarta sebesar 84. Hasil nilai rataan THI tersebut mengindikasikan adanya suhu kritis atau cekaman panas pada ternak, hal ini berdasarkan klasifikasi Pennington dan VanDevender (2004) nilai THI tersebut menunjukan terjadinya suhu kritis atau cekaman panas sedang pada ternak. Cekaman panas sedang ditandai dengan terjadinya pelepasan tubuh sebanyak 50\% melalui proses respirasi (Berman 2005). Pada kondisi iklim mikro tersebut, harus diperhatikan peternak di Indonesia untuk mengurangi pengaruh iklim mikro dengan beberapa cara yang disarankan oleh Velasco et al. (2002) melalui perbaikan manajemen pakan, imbangan nutrisi, pemberian air minum adlibitum, dan sirkulasi kandang. Usaha lain untuk peningkatan pemahaman efek lingkungan iklim mikro pada siang hari dengan ditandai terjadinya suhu kritis ternak dan cekaman panas menuntut peternak untuk memaksimalkan efek positif dan negatifnya (Coller et al. 2006). Waktu pemberian pakan dan pemberian pakan yang memiliki heat increamentrelatif rendah dengan berdasarkan suhu kritis ternak 
disarankan untuk dilakukan bila siang hari ada cekaman iklim panas di daerah pengembangan sapi perah.

Kecepatan angin berfungsi mengalirkan udara yang bersuhu lebih tinggi di sekitar ternak ke tempat yang lain. Selain itu, angin dapat membantu proses konveksi dan evaporasi panas dari tubuh ternak ke lingkungan. Pada pagi menuju siang hari, kecepatan angin meningkat seiring meningkatnya suhu udara, sehingga peningkatan kecepatan angin belum banyak berpengaruh pada penurunan cekaman panas tubuh ternak, sebaliknya sore hari semakin menurun. Rataan kecepatan angin pada siang dan sore hari di daerah Bogor dan Jakarta masih relatif rendah yaitu $0,4 \mathrm{~m} / \mathrm{s}$ dan $0,2 \mathrm{~m} / \mathrm{s}$ serta $0,1 \mathrm{~m} / \mathrm{s}$ dan $0,08 \mathrm{~m} / \mathrm{s}$. Pemberian kecepatan angin 1,12-1.30 m/s akan membantu sapi FH mengatasi suhu kritis ternak atau cekaman panas (Lee dan Keala 2005). Perpindahan panas dengan konveksi dan evaporasi antara ternak dengan lingkungan dipengaruhi kecepatan angin sebesar 25\%. Angin dapat digunakan untuk membantu mereduksi cekaman panas pada ternak (Beede dan Colier 1986).

\section{Respon Fisiologis Ternak}

Suhu rektal merupakan salah satu parameter dari pengaturan suhu tubuh yang umum digunakan, karena kisaran suhunya relatif lebih konstan dan lebih mudah pengukuran di lapangan. Hasil pengukuran suhu rektal harian ternak di daerah Bogor dan Jakarta sebagian besar masih dalam kisaran normal, yaitu berkisar antara $38,47-39,21^{\circ} \mathrm{C}$ dan $38,34-39,58^{\circ} \mathrm{C}$. Kisaran suhu rektal normal untuk sapi perah antara $38,2-39,1^{\circ} \mathrm{C}$ (Schutz et al. 2009). Pada penelitian ini, untuk daerah Bogor dan Jakarta, suhu rektal terendah terjadi pada pukul 05.00 (pagi) dan meningkat setelah ternak mengkonsumsi pakan dan seiring meningkatnya suhu udara (Gambar 2). Suhu rektal meningkat selama stress panas $\left(40,4^{\circ} \mathrm{C}\right)$ dapat mengurangi konsumsi bahan kering sebanyak 30\% (Wheelock et al. 2010).

Berdasarkan grafik pada Gambar 2, suhu rektal ternak mulai mengalami stress panas pada siang hari pukul 12.00 saat suhu udara tertinggi, suhu rektal di bogor $\left(39,04^{\circ} \mathrm{C}\right)$ dan Jakarta $\left(39,22^{\circ} \mathrm{C}\right)$. Suhu rektal tertinggi di Bogor dan Jakarta terjadi pada sore hari pukul $17.00\left(39,05^{\circ} \mathrm{C}\right)$ dan pukul $16.00\left(39,13^{\circ} \mathrm{C}\right)$. Peningkatan suhu rektal tersebut diakibatkan adanya peningkatan panas metabolisme tubuh, karena ternak baru mengkonsumsi pakan, dan juga disebabkan proses homeostasis ternak setelah terjadi gangguan homeostasis pada siang hari. Hasil penelitian Purwanto et al. (1993) serta Kendal et al. (2006) melaporkan bahwa pada suhu lingkungan $30^{\circ} \mathrm{C}$ serta $32,2^{\circ} \mathrm{C}$, suhu rektal dapat mencapai lebih dari $39,8^{\circ} \mathrm{C}$ serta $40^{\circ} \mathrm{C}$. Kondisi suhu rektal yang tinggi tersebut, mengindikasikan fungsi tubuh bekerja secara ekstra 
untuk mencapai keseimbangan panas yang baik dengan pelepasan panas. Untuk mengetahui suhu kritis (suhu dan kelembaban udara) di sekitar kandang sapi perah berdasarkan suhu rektal sapi dara dapat digunakan hasil simulasi ANN.

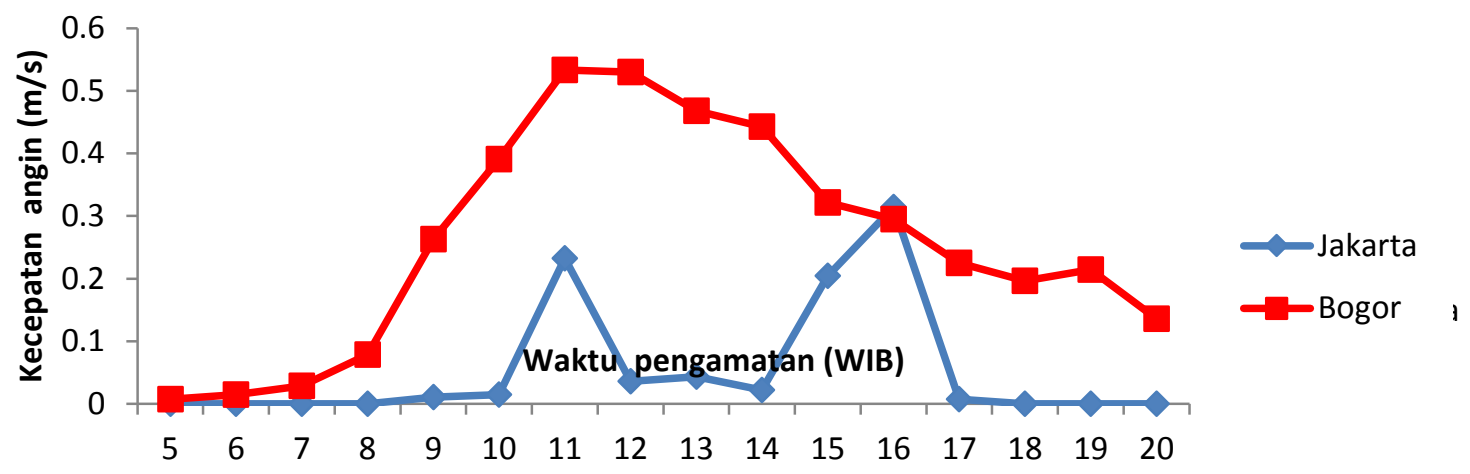

Gambar 1.Rataan Fluktuasi suhu udara, kelembaban udara, indeks suhu kelembaban dan Kecepatan angin.

Permukaan kulit hewan dapat berfungsi untuk melepaskan atau tempat pembuangan panas yang utama melalui proses radiasi, konveksi, konduksi, dan evaporasi (Berman 2003). Pada penelitian ini, suhu kulit harian ternak di daerah Bogor dan Jakarta sebagian masih dalam kisaran normal, yaitu berkisar antara $28,84-35,01^{\circ} \mathrm{C}$ dan $29,38-33,91^{\circ} \mathrm{C}$. Suhu kulit sapi yang dipelihara pada lingkungan mikro yang nyaman yaitu berkisar antara $33,5-37,1^{\circ} \mathrm{C}$ (Tucker et al. 2008). Suhu kulit terendah di Bogor dan Jakarta yaitu pada pukul 05.00 pagi $\left(29,22^{\circ} \mathrm{C}\right)$ dan $\left(30,36^{\circ} \mathrm{C}\right)$. Suhu kulit tertinggi pada pukul 12.00 siang $\left(34,31^{\circ} \mathrm{C}\right)$ dan $\left(33,78^{\circ} \mathrm{C}\right)$ masing-masing untuk Bogor dan Jakarta. Suhu kulit tertinggi di Bogor dan Jakarta terjadi pada sore hari pukul $17.00\left(32,28^{\circ} \mathrm{C}\right)$ dan pukul $16.00\left(33,40^{\circ} \mathrm{C}\right)$ (Gambar 3).

Pada saat suhu tinggi, tubuh akan mengeluarkan keringat dalam jumlah banyak serta memperlebar pembuluh darah (vasodilatasi) sehingga panas akan terbawa keluar dari tubuh.

Sebaliknya, pada saat suhu rendah, suhu tubuh akan mengeluarkan lebih sedikit keringat dan mempersempit pembuluh darah (vasokonstriksi) sehingga mengurangi pengeluaran 
panas oleh tubuh. Kulit sangat berkorelasi dengan fluktuasi unsur cuaca karena mengalami kontak langsung dengan cuaca. Suhu permukaan tubuh bervariasi berdasarkan kadar uap air lingkungan, lokasi kandang (naungan), dan ventilasi (Marcilae 2009).

Proses pelepasan panas melalui kulit terjadi melalui mekanisme vasodilatasi. Mekanisme vasodilatasi yaitu pembuluh darah mengembang untuk berdekatan dengan kulit (lingkungan luar) yang memungkinkan panas dibebaskan keluar. Bulu kulit ditegakkan untuk mengurangi udara yang terperangkap pada kulit supaya panas mudah dibebaskan karena udara adalah konduktor panas yang baik. Ganong (1983) mengemukakan jumlah panas yang hilang dari tubuh dalam batasbatas yang luas di atur oleh perubahan jumlah darah yang mengalir melului kulit. Kulit berperan penting dalam menerima rangsangan panas atau rangsangan dingin untuk dihantarkan ke susunan syaraf pusat dan diteruskan ke hipotalamus bagian pre optic. Rangsangan suhu tersebut diteruskan ke pusat pengatur panas yang juga di hipotalamus untuk melakukan usaha-usaha penurunan produksi atau pengeluaran panas (Isnaeni 2006). Suhu tubuh merupakan perwujudan dari suhu organ-organ di dalam tubuh serta organ-organ di luar tubuh. Suhu di dalam tubuh diwakili oleh suhu rektal dan suhu di luar tubuh diwakili oleh suhu permukaan kulit. Peningkatan beban panas yang disebabkan oleh kombinasi suhu udara, kelembaban udara, pergerakan udara, dan radiasi matahari dapat meningkatkan suhu tubuh dan frekuensi respirasi serta mengurangi konsumsi pakan dan produksi susu (Hahn 1999; Ominski et al. 2002; West 2003). Hasil perhitungan suhu tubuh harian ternak di daerah Bogor dan Jakarta sebagian masih dalam kisaran normal, yaitu berkisar antara $37,18-38,50^{\circ} \mathrm{C}$ dan $37,24-38,77^{\circ} \mathrm{C}$. Suhu tubuh sapi yang dipelihara pada lingkungan mikro yang nyaman yaitu berkisar antara 38,3-38,6 $6^{\circ} \mathrm{C}$ (Schutz et al. 2008). Suhu tubuh terendah di Bogor dan Jakarta yaitu pada pukul 05.00 pagi $\left(37,29^{\circ} \mathrm{C}\right)$ dan $\left(37,65^{\circ} \mathrm{C}\right)$ serta meningkat seiring meningkatnya beban panas dari lingkungan dan dari hasil metabolisme. Respon suhu tubuh terhadap stress panas berbeda-beda tiap individu dan respon tersebut disebabkan oleh produksi dan pelepasan panas tubuh. Suhu tubuh tertinggi pada pukul 12.00 siang $\left(38,37^{\circ} \mathrm{C}\right)$ dan $\left(38,45^{\circ} \mathrm{C}\right)$ masing-masing untuk Bogor dan Jakarta (Gambar 4). Sementara itu suhu tubuh tertinggi di Bogor dan Jakarta terjadi pada sore 
hari pukul $17.00\left(32,28^{\circ} \mathrm{C}\right)$ dan pukul $16.00\left(33,40^{\circ} \mathrm{C}\right)$.

Suhu tubuh dapat dijadikan indikator dalam menentukan dimulai cekaman panas pada ternak yang disebabkan lingkungan mikro dan pakan. Pengaturan suhu tubuh dilakukan melalui mekanisme umpan balik oleh saraf eferen, hipotalamus, dan efektor saraf eferen. Bagianbagian tersebut berfungsi sebagai termostat dengan hipotalamus sebagai pusat kontrolnya. Tubuh akan mempertahankan suhu tubuhnya dengan menyeimbangkan pembentukan dan pelepasan panas. Suhu dan kelembaban udara dalam kandang yang termasuk iklim mikro merupakan dua faktor iklim yang mempengaruhi produksi sapi perah, karena dapat menyebabkan perubahan keseimbangan panas dalam tubuh ternak, keseimbangan air, keseimbangan energi dan keseimbangan tingkah laku ternak (Hafez dan Bouissou 1975).

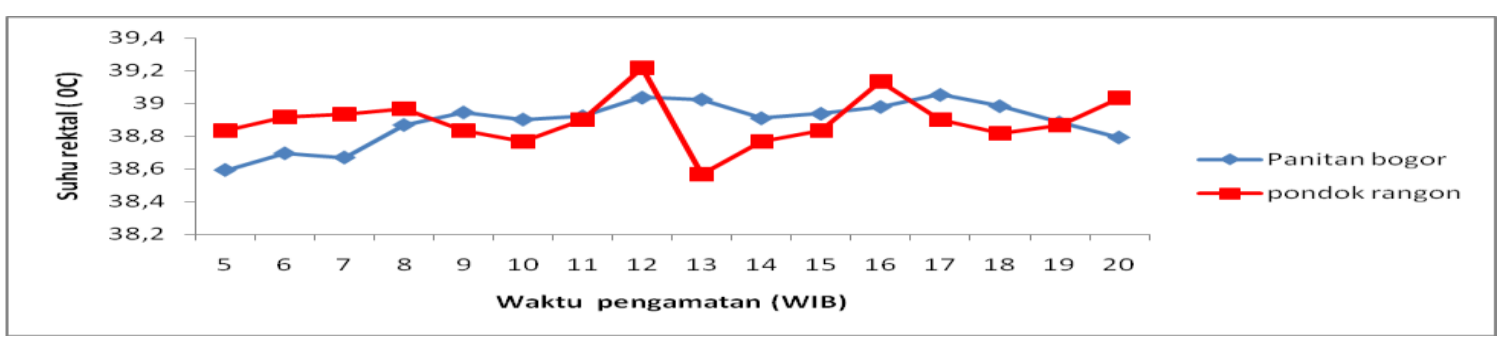

Gambar 2 Rataan fluktuasi suhu rektal (Tr) sapi dara PFH tiap jam dari pukul 05.00 hingga pukul 20.00 antara daerah Bogor dengan Jakarta

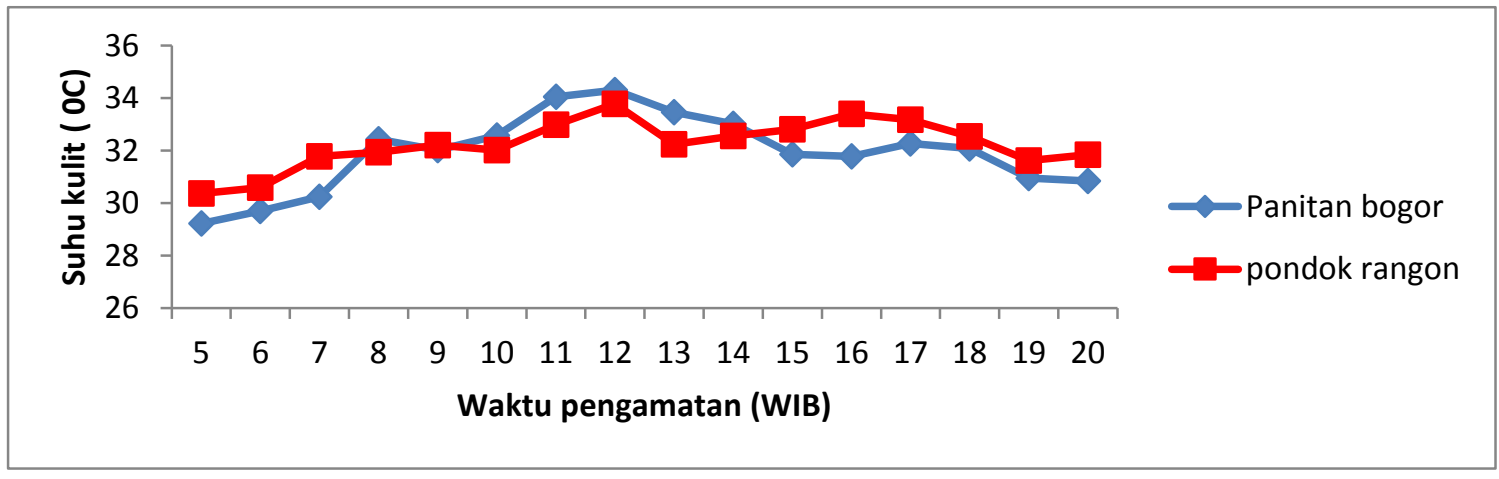

Gambar 3 Rataan fluktuasi suhu kulit sapi dara PFH tiap jam dari pukul 05.00 -pukul 20.00 antara daerah Bogor dengan Jakarta 


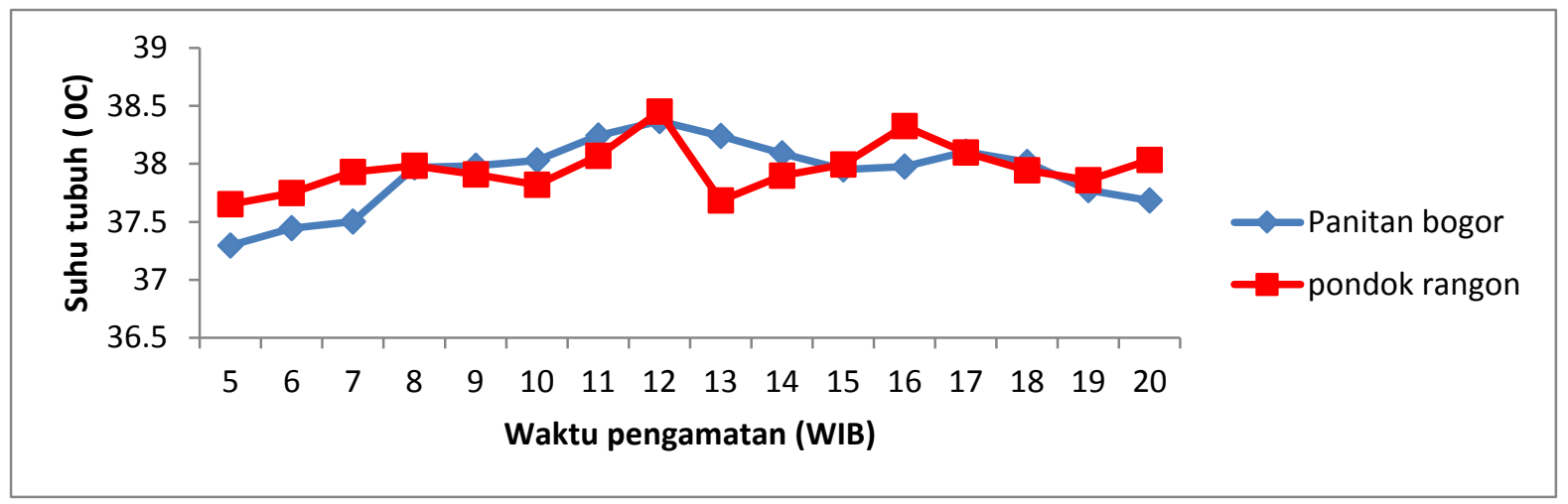

Gambar 4 Rataan fluktuasi suhu tubuh $(\mathrm{Tb})$ sapi dara PFH tiap jam dari pukul 05.00 hingga pukul 20.00 antara daerah Bogor dengan Jakarta

ModelPendugaan Suhu Kritis Berdasarkan Indikator Respon Fisiologis Melalui Simulasi ANN

Aplikasi program ANN merupakan langkah metode pelatihan propagasi balik yang dilakukan terhadap data-data pelatihan dengan harapan kesalahan (error) terkecil. Setelah dilakukan iterasi berulangulang dihasilkan nilai kesalahan yang fruktuasi serta nilai kesalahan yang semakin menurun dari setiap iterasi. Nilai kesalahan yang terkecil pada output prediksi terhadap output target, baik di daerah Bogor maupun Jakarta pada $Y_{\mathrm{p} 1}$ (suhu rektal) dan $\mathrm{Y}_{\mathrm{p} 2}$ (suhu kulit) yaitu setelah dilakukan iterasi sebanyak 2.100.000/100 (21.000 kali). Masing-masing di daerah Bogor dan Jakarta diperoleh nilai error pada suhu rektal sebesar 0,199510 dan 0,693969, suhu kulit sebesar 0,392903 dan 0,828096.

Langkah validasi hasil ANN pada suhu rektal (Tr) dan suhu kulit (Ts) rectal dan suhu kulit hasil perhitungan ANN dibandingkan dengan hasil pengukuran di lapang. Pelaksanaan validasi dilakukan pada kondisi suhu dan kelembaban udara yang sama antara data hasil perhitungan ANN dan hasil pengukuran di lapang. Selanjutnya validasi dimulai setelah didapatkan nilai error terendah, kemudian dilakukan proses normalisasi kembali, yaitu normalisasi data input $\left(\mathrm{x}_{1}, \mathrm{x}_{2}\right)$, data target $\left(\mathrm{yt}, \mathrm{y}_{\mathrm{t} 2}\right.$, ) dan hasil prediksi perhitungan ANN (yp1, yp2)

Nilai validasi menunjukkan kecenderungan hasil perhitungan ANN mendekati hasil pengukuran 
penelitian lapang dengan rataan nilai persentase error yang rendah, masingmasing untuk daerah Bogor dan Jakarta yaitu $\mathrm{yp}_{\mathrm{p} 1}=0,65 \%$ dan $0,80 \%$, $\mathrm{yp}_{\mathrm{p} 2}$ $=1,34 \%$ dan $1,40 \%$. Pada beberapa titik validasi terjadi perbedaan persentase error yang cukup besar, tetapi masih relatif dalam batasan yang rendah $(\%$ error $<5 \%$ ). Hasil nilai tersebut dapat diartikan bahwa nilai prediksi sudah mendekati nilai aktualnya. Nilai persentase error yang rendah menunjukkan bahwa hasil perhitungan ANN memiliki akuarasi yang tinggi sehingga dapat dijadikan acuan untuk suhu dan kelembaban udara dalam penentuan suhu kritis sapi dara di daerah Bogor dan Jakarta.

Simulasi merupakan teknik penyusunan dari kondisi yang nyata dan kemudian melakukan penelitian pada model yang dibuat dari sistem. Pada simulasi ini dilakukan dengan memperhatikan parameter suhu dan kelembaban udara sebagai penentu suhu kritis dengan respon fisiologis ternak untuk setiap kondisi mulai dari nilai minimum sampai nilai maksimum yang terukur pada penelitian. Pada simulasi dengan mengkombinasi nilai input suhu dan kelembaban udara, maka didapatkan variasi nilai output suhu rektal dan suhu kulit di daerah Bogor dan Jakarta. Berdasarkan hasil simulasi suhu dan kelembaban udara, maka dapat mengetahui berapa respon fisiologis sapi perah pada suhu rectal dan suhu kulit, tanpa perlu mengukur langsung kepada ternaknya, tetapi cukup melihat suhu dan kelembaban udara yang terukur saat itu, kemudian disimulasikan dengan ANN. Hasil simulasi dapat digunakan untuk mengetahui tingkat respon fisiologis sapi perah ( $\mathrm{Tr}$ dan $\mathrm{Ts}$ ) terhadap perubahan suhu dan kelembaban udara yang berbeda. Hasil simulasi menggunakan ANN tertera pada Tabel 3

Hasil prediksi dari simulasi ANN menunjukkan bahwa semakin meningkat suhu udara, maka semakin meningkat pula suhu rektal dan suhu kulit sapi perah baik daerah Bogor maupun Jakarta (Tabel 3). Begitu juga, semakin meningkat kelembaban udara baik pada suhu yang sama atau pada suhu udara yang meningkat mengakibatkan peningkatan suhu rektal dan suhu kulit. Berdasarkan hasil simulasi ANN dapat diperoleh korelasi anatara suhu dan kelembaban udara dengan tingkat cekaman panas (suhu kritis) sapi berdasarkan suhu rektal dan suhu kulit. Kisaran suhu rektal normal untuk sapi perah antara 38,2 - 39, $1^{\circ} \mathrm{C}$ (Schutz et al. 2009). Tucker et al. (2008) mengemukakan bahwa suhu permukaan kulit sapi yang dipelihara pada lingkungan mikro nyaman berkisar antara $33,5-37,1^{\circ} \mathrm{C}$. 
Berdasarkan hal tersebut, maka dapat dikatakan bahwa sapi perah mengalamami cekaman panas apabila suhu rektal lebih dari $39,1^{\circ} \mathrm{C}$ dan suhu kulit lebih dari $37,1^{\circ} \mathrm{C}$.

Berdasarkan hasil prediksi hasil simulasi ANN, perubahan suhu dan kelembaban udara sangat sensitif

Peningkatan kelembaban udara dan suhu udara yang sama dan suhu udara berbeda sangat mempengaruhi terhadap suhu kritis pada sapi perah. Pada saat udara $22,50-25,50^{\circ} \mathrm{C}$ baik di daerah Bogor maupun Jakarta belum terjadi suhu kritis(cekaman panas) meskipun terjadi perubahan kelembaban udara. Suhu udara dan kelembaban udara tersebut, suhu rektal dan suhu kulit masih pada kisaran normal. Saat suhu udara 26$32^{\circ} \mathrm{C}$ (Bogor) dan suhu udara 26$33,50^{\circ} \mathrm{C}$ (Jakarta), sapi perah mulai terjadi suhu kritis (cekaman panas) dengan indikator cekaman panas pada suhu rektal. Pada saat peningkatan kelembaban udara dengan suhu udara yang sama dan suhu udara yang berbeda sangat mempengaruhi mempengaruhi suhu rektal dan suhu kulit pada sapi perah.Tingkat suhu kritis berdasarkan suhu rektal dan suhu kulit pada suhu dan kelembaban udara yang berbeda baik di daerah Bogor maupun Jakarta dapat dilihat pada Tabel 2.

terhadap perubahan suhu rektal dibandingkan perubahan suhu kulit. Suhu kritis dengan indikator suhu kulit mulai terjadi apabila suhu udara naik menjadi $31^{\circ} \mathrm{C}$ dengan kelembaban udara 86\% (Bogor) dan suhu udara naik menjadi $32,50^{\circ} \mathrm{C}$ dan kelembaban udara 88\% (Jakarta). Pada saat suhu udarayang tinggi yaitu $31-32^{\circ} \mathrm{C}$ dan $32,50-33,50^{\circ} \mathrm{C}$ masing-masing untuk daerah Bogor dan Jakarta, terjadi suhu kritis (cekaman) panas dengan indikator suhu rektal dan suhu kulit, tetapi suhu rektal lebih sensitif dibandingkan suhu kulit, karena suhu rektal dipengaruhi baik dari lingkungan eksternal berasal dari iklim mikro maupun berasal dari panas tubuh. 
Tabel 1. Hasil simulasi ANN perkiraan suhu rektal (Tr) dan suhu kulit (Ts) pada suhu dan kelembaban udara yang berbeda di daerah Bogor dan Jakarta

\begin{tabular}{|c|c|c|c|c|c|c|c|}
\hline \multicolumn{5}{|c|}{ Bogor } & \multicolumn{3}{|c|}{ Jakarta } \\
\hline $\begin{array}{c}\text { Suhu udara } \\
\left({ }^{\circ} \mathrm{C}\right)\end{array}$ & $\begin{array}{l}\text { Kelembaba } \\
\text { n udara }(\%)\end{array}$ & $\begin{array}{c}\text { Suhu rektal } \\
\left({ }^{\circ} \mathrm{C}\right)\end{array}$ & $\begin{array}{c}\text { Suhu kulit } \\
\left({ }^{\circ} \mathrm{C}\right)\end{array}$ & $\begin{array}{c}\text { Suhu udara } \\
\left({ }^{\circ} \mathrm{C}\right)\end{array}$ & $\begin{array}{l}\text { Kelembaba } \\
\text { n udara }(\%)\end{array}$ & $\begin{array}{c}\text { Suhu rektal } \\
\left({ }^{\circ} \mathrm{C}\right)\end{array}$ & $\begin{array}{c}\text { Suhu kulit } \\
\left({ }^{\circ} \mathrm{C}\right)\end{array}$ \\
\hline 24 & 86 & 38,86 & 31,52 & 24 & 88 & 38,75 & 30,10 \\
\hline 24 & 84 & 38,88 & 31,14 & 24 & 86 & 38,80 & 30,73 \\
\hline 24 & 82 & 38,89 & 30,74 & 24 & 84 & 38,85 & 30,86 \\
\hline 26 & 86 & 39,11 & 32,23 & 26 & 88 & 39,13 & 31,13 \\
\hline 26 & 84 & 38,83 & 32,12 & 26 & 86 & 38,98 & 31,67 \\
\hline 26 & 82 & 38,83 & 31,86 & 26 & 84 & 38,94 & 31,08 \\
\hline 28 & 86 & 39,23 & 35,35 & 27,50 & 88 & 39,11 & 32,00 \\
\hline 28 & 84 & 39,15 & 33,71 & 27,50 & 86 & 38,93 & 31,85 \\
\hline 28 & 82 & 39,01 & 32,61 & 27,50 & 84 & 38,84 & 31,81 \\
\hline 30 & 86 & 39,14 & 35,15 & 29 & 88 & 39,11 & 31,88 \\
\hline 30 & 84 & 39,11 & 33,02 & 29 & 86 & 38,96 & 31,80 \\
\hline 30 & 82 & 38,87 & 32,89 & 29 & 84 & 38,93 & 31,76 \\
\hline 32 & 86 & 39,26 & 37,26 & 33 & 66 & 39,13 & 32,32 \\
\hline 32 & 84 & 39,17 & 34,76 & 33 & 64 & 39,20 & 32,32 \\
\hline 32 & 82 & 38,89 & 31,76 & 33 & 62 & 39,27 & 32,33 \\
\hline
\end{tabular}

Tabel 2 Suhu dan kelembaban udara pada saat sapi perah mulai mengalami suhu kritis (cekaman panas) dengan indikator suhu rektal (Tr) dan suhu kulit (Ts) di daerah Bogor dan Jakarta

\begin{tabular}{cccccc}
\hline & Bogor & & \multicolumn{3}{c}{ Jakarta } \\
\hline Suhu udara $\left({ }^{\circ} \mathrm{C}\right)$ & Kelembaban udara & $\begin{array}{c}\text { Indikator } \\
\text { cekaman } \\
\text { panas }\end{array}$ & $\begin{array}{c}\text { Suhu udara } \\
\left({ }^{\circ} \mathrm{C}\right)\end{array}$ & $\begin{array}{c}\text { Kelembaba } \\
\text { n udara } \\
(\%)\end{array}$ & $\begin{array}{c}\text { Indikator } \\
\text { cekaman } \\
\text { panas }\end{array}$ \\
\hline $22,50-25,5$ & 60 & - & $23,5-25,5$ & 58 & - \\
26 & 86 & $\operatorname{Tr}$ & 26 & 88 & $\mathrm{Tr}$ \\
27 & 84 & $\mathrm{Tr}$ & 27,5 & 88 & $\mathrm{Tr}$ \\
28 & 84 & $\mathrm{Tr}$ & 29 & 88 & $\mathrm{Tr}$ \\
29 & 84 & $\mathrm{Tr}$ & 30,5 & 88 & $\mathrm{Tr}$ \\
30 & 84 & $\mathrm{Tr}$ & 31 & 84 & $\mathrm{Tr}$ \\
31 & 86 & $\mathrm{Ts}$ & 32 & 82 & $\mathrm{Tr}$ \\
31 & 84 & $\mathrm{Tr}$ & 32,5 & 88 & $\mathrm{Ts}$ \\
32 & 84 & $\mathrm{Tr}$ & 33 & 66 & $\mathrm{Tr}$ \\
32 & 86 & $\mathrm{Ts}$ & 33 & 78 & $\mathrm{Ts}$ \\
\hline
\end{tabular}




\section{KESIMPULAN}

1. Model penerapan Artificial Neural Network (ANN) dapat digunakan untuk menentukan suhu kritis berdasarkan peubah suhu dan kelembaban udara di dalam kandang sapi perah $\mathrm{PFH}$ terhadap respon fisiologisnya dengan indikator suhu rektal dan suhu permukaan kulit.

2. Peningkatan kelembaban dan suhu udara yang sama dan suhu udara berbeda sangat mempengaruhi terhadap suhu kritis pada sapi perah. Suhu udara berkisar antara 22,50-25,50 ${ }^{\circ} \mathrm{C}$ baik di daerah Bogor maupun Jakarta belum terjadi suhu kritis meskipun terjadi perubahan kelembaban udara.

3. Suhu udara $26^{\circ} \mathrm{C}$ dengan kelembaban udara $86 \%$ di Bogor dan Suhu udara $26^{\circ} \mathrm{C}$ dengan kelembaban udara 88\% di Jakarta, sapi perah mulai terjadi suhu kritis dengan indikator cekaman panas pada suhu rektal. Suhu kritis dengan indikator suhu kulit mulai terjadi pada suhu udara $31^{\circ} \mathrm{C}$ dengan kelembaban udara 86\% (Bogor) dan suhu udara naik menjadi $32,50^{\circ} \mathrm{C}$ dan kelembaban udara 88\% (Jakarta). Suhu rektal lebih sensitif dibandingkan suhu kulit. Semakin meningkat suhu rektal sapi perah lebih sensitif dipengaruhi perubahan kelembaban dan suhu udara

\section{DAFTAR PUSTAKA}

Beede DK, Coolier RJ. 1986. Potential nutritions for intensive managed cattle during thermal stress. J Anim Sci 62: 543.

Berman A. 2005. Estimates of heat stress relief needs for Holstein dairy cows. J Anim Sci 83: 13771384.

Berman A. 2008. Increasing heat stress relief produced by coupled coat wetting and forced ventilation. J Dairy Sci 91: 4571-4578.

Berman A. 2010. Forced heat loss from body surface heat flow to body surface.J Dairy Sci 93:242-248.

Bohmanova J, Misztal I, Cole JB. 2007. Temperature-humidity indices as indicators of milk production losses due to heat stress. J Dairy Sci 90: 1947-1956.

Brosh Aet al. Effect of solar radiation, dietary energy, and time of feeding on thermoregulatory responses and energy balance in cattle in a hot environment. J Anim Sci 76: 2671-2677.

Collier RJ, Dahl GE, VanBaale MJ. 2006. Major advances associated with environmental effects on dairy cattle. J Dairy Sci 89: 12441253.

Ganong. 1983. Review of Medical Physiology.Ed ke-11. California: Lange Medical Publication.

Gebremedhin KG. 1985. Heat Exchange Between Livestock and Environment. Dalam: 
Yousef MK, editor. Stress Physiology of Livestock.Volume ke-1, Basic Principle. Florida: CRC Press Inc.

Hafez ESE, Bouissou MF. 1075. The behaviourr of cattle. Dalam: Behaviour of Domestic Animals.Ed ke-3. Baltimore: Williams and Wilkims Co.

Hahn GL. 1999. Dynamic responses of cattle to thermal heat loads. J Anim Sci 77: 10-20

Isnaeni W. 2006.Fisiologi Hewan. Penerbit Kanisius: Yogyakarta.

Jones GM, CC Stallings. 1999. Reducing heat stress for dairy cattle. Virginia Cooperative Extension. Publication Number 404-420.

http://www.ext.edu/index.html. [21 Oktober 2005].

Kelly WR. 1984. Veterinary Clinical Diagnosis. London: Bailliere Tindall.

Kendall PE et al. 2006. The effect of providing shade to lactating dairy cows in a temperate climate.Livest Sci 103: 148-157.

Kusumadewi S. 2003. Artificial Intelligence (Teknik dan Aplikasinya). Graha Ilmu, Yogyakarta.

Lee CN, Keala N. 2005. Evalution of cooling system to improve lactating Holstein cows comfort in the sub-tropics. J Anim Sci 82: 128-136.

Marcilac-Emberston NM et al. 2009. Effect of shade and sprinklers on performance, behavior, physiology, and the environment of heifers.J Dairy Sci 92: 506-517.

McDowell RE. 1972. Improvement of Livestock Production in Warm Climate. WH Freeman and Co. San Fransisco.

McLean JA, Downie AJ, Jones CDR, Strombough DP, Glasbey CA. 1983.Thermal adjustments of stress (Bos Taurus) to abrupt changes in environments temperature.Camb J Agric Sci 48:81-84.

McNeilly AS. 2001. Reproduction, fertility, and development. CSIRO Publishing 13:583-590.

Ominski KH et al. 2002. Physiological and production responses to feeding schedule in lactating dairy cows exposed to shortterm, moderate heat stress. J Dairy Sci 85:730-737.

Pennington JA, VanDevender K. 2004. Heat Stress in Dairy Cattle.http://www.uaex.edu/oth er areas/publication/html [19 Mei 2004].

Purwanto BP et al. 1993. Effect of standing and lying behaviours on heat production of dairy heifers differing in feed intake levels.AJAS 6: 271-274.

Rahardja DP. 2007. Ilmu Lingkungan Ternak. Makassar: Citra Emulsi.

Santoso AB et al. 2003. Pengaruh lingkungan mikro terhadap 
respons fisiologi sapi dara peranakan Fries Holland. Forum Pascasarjana vol 26(4): 277-288.

Schirman K et al. 2009. Technical note: Validation of a system for monitoring ruminansia in dairy cows. J Dairy Sci 92: 6052-6055.

Schutz KE, Cox NR, Matthews LR. 2008. How important is shade to dairy cattle? Choice between shade or lying following different levels of lying deprivation. Appl Anim Behav Sci 114:307-318.

Schutz KE, Rogers AR, Cox NR, Tucker CB. 2009. Dairy cows prefer shade that offers greater protection against solar radiation in summer: shade use, behavior, and body temperature. Appl Anim Behav Sci 116:28-34.

Schutz KE et al. 2010. The amount of shade influences the behavior and physiology of dairy cattle. $J$ Dairy Sci 93: 125-133.

Schutz KE et al. 2011. Dairy cattle prefer shade over sprinklers: Effects on behaviuor and physiology.J Dairy Sci 94: 273283.

Sudono A, Rosdiana RF, Setiawan BS. 2003. Beternak Sapi Perah Secara
Intensif. Cetakan ke-2. AgroMedia Pustaka, Bogor.

Tucker CB, Rogers AR, Schutz KE. 2008. Effect of solar radiation on dairy cattle behaviuor, use of shade and body temperature in a pasture-based system.Appl Anim Behav Sci 109:141-154.

Tyler HD, Enseminger ME. 2006. Dairy Cattle Science. Pearson edution, Inc. Upper Saddle River, New Jersey.

Velasco NB, Arguzon JA, Briones JI. 2002. Reducing heat stress in dairy cattle:

Phlippines.International Training on Strategies for Reducing Heat Stress in Dairy Cattle.Taiwan Livestock Research Institute (TLRI-COA) August 26-31, 2002, Tainan, Taiwan, ROC.

West JW. 2003. Effects of heat stress on production in dairy cattle. $J$ Dairy Sci 86:2131-2141

Wheelock JB et al. 2010. Effects of heat stress on energetic metabolism in lactating Holstein cows. $J$ Dairy Sci 93: 644-655.

Yousef MK. 1985. Thermoneutral Zone. In: Stress Physiology of Livestock. Volume II, Basic Principle. Florida: CRC Press Inc. 